\title{
O Ensino Da Consciência Moral Cristã Nas Representações De "Tentações De Santo Antão": Da Mesa dos Pecados de Bosch às gravuras de Jacques Callot da Biblioteca Nacional
}

\author{
Fellipe Eduardo Gonçalves Amorim ${ }^{1}$ \\ DOI 10.20396/eha.vil4.3326
}

Após o período de fundamentação teórica desenvolvido entre os séculos VII e XII, baseandose em passagens bíblicas que justificavam e defendiam a utilização das imagens religiosas diante do movimento iconoclasta ocidental, houve uma maior mudança e abertura na relação funcional ${ }^{2}$ das imagens religiosas cristãs, que passaram a aderir segundo Baschet, uma condição de imagem -objeto, permitindo que o fiel tivesse a experiência da imagem até mesmo em objetos como o pão e vinho, transubstanciados no corpo e sangue de Cristo.

Desta forma, a noção de imagem presente no cotidiano medieval estaria não só nas representações feitas dentro das Igrejas (nos retábulos e afrescos), como dentro da linguagem, das metáforas, alegorias e pregações. O que, segundo Schmitt ${ }^{3}$, justificaria as visões ou imagens mentais individuais, incitadas pelas relações estabelecidas com as imagens ou objetos religiosos que serviam de representações devocionais tanto para os clérigos, quanto para os fiéis.

O que de acordo com Pierre Bourdieu ${ }^{4}$, seria um poder simbólico, uma forma invisível de influenciar o pensamento, criando uma verdade reconhecida e respeitada universalmente. Utilizando meios estruturados e estruturantes como a arte, a religião e a língua, para defender os ideais que seriam capazes de atingir as diferentes esferas de conhecimento social, criando sua própria ideologia dentro do sistema cultural, gerando uma nova realidade.

Vivendo em um período artístico bastante influenciado pelos novos aspectos de produção, Hieronymus Bosch (1450-1516), seguiu um caminho diferente com seus quadros inovadores diante do conteúdo religioso e moral, recheando-os de figuras grotescas e cenários maravilhosos ${ }^{5}$. Fazen-

\footnotetext{
1 Instituto de Artes - UER] - Graduando em História da Arte - Bolsista de Iniciação Científica pela Fundação de Amparo à Pesquisa do Estado do Rio de Janeiro - FAPER].

2 Indicadas tanto pelo Papa Gregório Magno, quanto por diversos teóricos ao longo da história, como São Boaventura (1218 - 1274) e Santo Tomás de Aquino (1227 - 1274), abriu caminho para um pensamento sobre o conjunto de funções de ferramenta de instrução dos fiéis das imagens. Desta maneira, o ato de aprender através das imagens incitaria recordações nos fiéis, alimentando o pensamento das coisas santas, comovendo o espírito e suscitando sentimento de culpa, capaz de levar o fiel a conversão através do arrependimento.

3 SCHMITT, Jean-Claude. 2017, p.658-674.

4 BOURDIEU, Pierre. 2011.

5 Adotando aqui, o conceito segundo Jacques Le Goff, ao afirmar que, a maioria das civilizações e também a civilização medieval foram fascina-
} 
do parte da Confraria de Nossa Senhora e doando algumas de suas produções como forma de adquirir indulgências junto à Igreja, Bosch antes de ser um pintor era um fiel, exercendo sua crença a partir dos fundamentos advindos dos teólogos defensores das imagens. Em uma de suas representações mais famosas o pintor retratou em um tampo de mesa os Sete Pecados Mortais ${ }^{6}$ e os Quatro Novíssimos do Homem7 (FIGURA 1).

A obra, produzida para emular o olho de Deus sobre as atitudes pecaminosas do mundo, apresenta o Cristo no centro da composição olhando para o espectador e exibindo suas chagas. Ato que remete à crucificação, que, segundo as Escrituras, libertou o mundo dos pecados. Estes, observados no círculo externo distribuídos e representados em diferentes atitudes sociais do período de Bosch, criam uma relação direta com o momento da morte e do julgamento das almas pelo Cristo Juiz, responsável por decidir o destino do ser, aos céus ou ao inferno.

Esta tradição, envolvendo diferentes "formas simbólicas", demonstrando que a Igreja Cristã utilizou-se das ferramentas apontadas por Bourdieu ${ }^{8}$, estabelecendo assim, relações de comunicação e força, dando poder, tanto material, quanto simbólico aos agentes da Igreja. Ideologias construídas através das estruturas que exerciam funções sociais específicas de controle dentro da religião, foram determinantes para a constituição de um corpo de produtores especializados do conhecimento diante dos discursos e de ritos religiosos, "concedendo um espaço bem delimitado à experiência ou à vontade do agente social, reforçando o peso explicativo daquilo que manifesta acerca da realidade." ${ }^{\prime 9}$

Sendo a temática da fé e das relações de afastamento com os conhecimentos do mundo, presentes e marcantes na produção artística de Bosch, como uma forma de "Consciência Moral Cristã"10. Consciência essa, representada pela figura de Santo Antão que viveu no Egito durante o século III, conhecido como pai dos monges, termo derivado da raiz grega significando "só", ligando-o tam-

\footnotetext{
das pela temática do sobrenatural e extraordinário, suscitando reações religiosas, estéticas e mesmo científicas. Estando a temática ligada não só aos feitos de Deus mas também do Diabo, colocando em questão as relações do homem com Deus, com a natureza e com o Diabo. (LE COFF, Jacques. Maravilhoso. In: LE GOFF, Jacques, SCHMITT, Jean-Claude. Dicionário Analítico do Ocidente Medieval: Volume 2. São Paulo: Editora Unesp, 2017. p.120 - 138.)

6 Gula, Avareza, Luxúria, Ira, Inveja, Preguiça e Orgulho.

7 Nos Livros Santos chamam-se Novíssimos às coisas que sucederão ao homem no fim da vida: a morte, o juízo, o destino eterno: o céu ou o inferno.

8 BOURDIEU, Pierre, 2015.

9 BOURDIEU, Pierre, Op. Cit. 2015, p.11.

10 Definida no Catecismo da Igreja Católica como: A consciência moral é um juízo da razão, pelo qual a pessoa humana reconhece a qualidade moral dum acto concreto que vai praticar, que está prestes a executar ou que já realizou. Em tudo quanto diz e faz, o homem tem obrigação de seguir fielmente o que sabe ser justo e recto. E pelo juízo da sua consciência que o homem tem a percepção e reconhece as prescrições da lei divina: A consciência «é uma lei do nosso espírito, mas que o ultrapassa, nos dá ordens, e significa responsabilidade e dever, temor e esperança [...]. É a mensageira d'Aquele que, tanto no mundo da natureza como no da graça, nos fala veladamente, nos instrui e nos governa. A consciência é o primeiro de todos os vigários de Cristo» (Catecismo da Igreja Católica - Edição Típica Vaticana, Edições Loyola; Edição: 19 - 26 de maio de 1999).
} 
bém a representações do abandono dos bens mundanos de acordo com Lester Little" ${ }^{11}$, uma "fuga do mundo" e pela busca do real significado do ser cristão. Teve sua história representada diversas vezes ao longo da carreira do artista e devoto Hieronymus Bosch, apresentando o santo em seus momentos de luta e resistência diante das tentações físicas e psicológicas causadas pelo diabo. Inspiração retirada, segundo Stefan Fischer ${ }^{12}$, do Livro dos Santos contendo a história de Antão, escrita por Santo Atanásio no ano de 366.

Quando os demônios veem que os cristãos em geral, mas em particular os monges, trabaIham com cuidado e fazem progressos, primeiro os assaltam e tentam colocando-Ihes continuamente obstáculos em seus caminhos. Estes obstáculos são maus pensamentos. Mas não devemos assustar-nos com suas armadilhas que são logo desbaratadas com a oração, o jejum e a confiança no Senhor. No entanto, ainda que desbaratados, não cessam, mas antes voltam ao ataque com toda maldade e astúcia. ${ }^{13}$

As crescentes críticas sobre a Igreja de Roma, iniciadas ainda no século XV, pela venda de indulgências, massificação na veneração dos santos, e da suposta imoralidade dos Clérigos diante da sociedade, podem ter sido fatores que, juntamente à cultura religiosa já presente na vida de Bosch, influenciaram suas escolhas temáticas dentro das representações. Assim, os elementos presentes no quadro da Tentação de Santo Antão (FICURA 2), em que há diversas figuras com vestimentas religiosas em momentos de corrupção diante das tentações, podem confirmar críticas feitas pelo artista ao corpo da Igreja. Conteúdo desenvolvido anteriormente por Santo Agostinho ${ }^{14}$, ao afirmar que, por mais que Deus tenha criado todas as criaturas dotadas de bem, o homem provido de racionalidade e consciência de superioridade sobre as demais criaturas da Terra pode vir a corromper-se na busca pela materialidade e não mais pela salvação.

Em uma obra recheada de figuras demoníacas e subtemáticas sociais e religiosas, Bosch não deixou de abordar temáticas presentes nos escritos de Santo Atanásio ${ }^{15}$, como o momento em que o santo é levado pelos ares por demônios acusadores, presente na aba esquerda do tríptico:

Uma vez, por exemplo, à hora nona, quando se pôs de pé para orar antes de comer, sentiuse transportado em espírito e, estranho é dizê-lo, viu-se a si mesmo como se achasse fora de si mesmo e como se outros seres o levassem aos ares. Então viu também outros seres terríveis e abomináveis no ar, que lhe embargaram o passo. Defendendo-o seus conduto-

\footnotetext{
LITTLE, Lester K. 2017, p. 256 - 275.

FICHER, Stefan, 2019.

ATANÁSIO, Santo, 2019, p.31.

AGOSTINHO, Santo, 2019.

5 ATANÁSIO, Santo, Op. Cit. 2019.
} 
res, os outros perguntaram sob que pretexto queria fugir de sua responsabilidade diante deles. E quando começaram eles próprios a pedir-lhe contas desde seu nascimento, intervieram os guias de Antão: "Tudo o que data desde o seu nascimento o Senhor apagou; podem pedir-lhe contas desde que começou a ser monge e se consagrou a Deus". Então começaram a apresentar acusações falsas e como não as puderam provar, tiveram que deixar-Ihe livre a passagem. ${ }^{16}$

Segundo Quírico ${ }^{17}$, as críticas em relação às atitudes dos membros da Igreja foram intensificadas com Martinho Lutero (1483-1546), e o crescente interesse por seus protestos e reivindicações diante das atitudes da Igreja Católica fizeram com que a mesma buscasse uma resposta diante de tais críticas, com a intenção de retomar a autoridade e abolir o direito de cada indivíduo de julgar os problemas da consciência de acordo com sua razão pessoal. "A Reforma católica foi, portanto, não apenas uma reação ao protestantismo, mas também uma rejeição de muito a que o próprio Renascimento almejara."18

O desenrolar dos conflitos ideológicos ao longo do século XVI foi fator importante, segundo Quírico, para que a arte se tornasse um dos principais meios de propaganda da Igreja Católica contra os protestantes no século XVII, passando a enfatizar temas dogmáticos, vidas dos novos santos e mártires representados como grandes heróis da religião. Ferramenta que auxiliou a justificativa da riqueza e do esplendor, não apenas no meio da arte, como nos ofícios religiosos, que buscavam comover o fiel através do apelo emocional, diferindo-os das formas devocionais simples e intimistas utilizadas pelos protestantes.

Os acontecimentos posteriores desenvolveram disputas de poder entre os príncipes e autoridades eclesiásticas, assumindo grandes proporções, iniciando entre as grandes potências europeias uma das mais cruéis guerras causadas pela humanidade: a chamada Guerra dos Trinta Anos, travada entre os anos de 1618 e 1648, no território conhecido como Antigo Sacro Império Romano-Germânico. Enfrentamento visando a uma maior participação territorial, política e econômica dentro do continente europeu, envolvendo países como a Espanha, que defendia sua hegemonia no continente, a França - que, segundo Jackson Brandão ${ }^{19}$, tentava desestabilizar o poder dos Habsburgos na Espanha e na Áustria, e a Inglaterra que buscava condições para sua futura dominação dos mares.

\footnotetext{
16 ATANÁSIO, Santo, Op. Cit. 2019, p.60-61.

17 QUÍRICO, Tamara. 2012, p.117-140.

18 QUÍRICO, Tamara, 2012, p.123.

19 BRANDÃO, Jackson, 2012.
} 


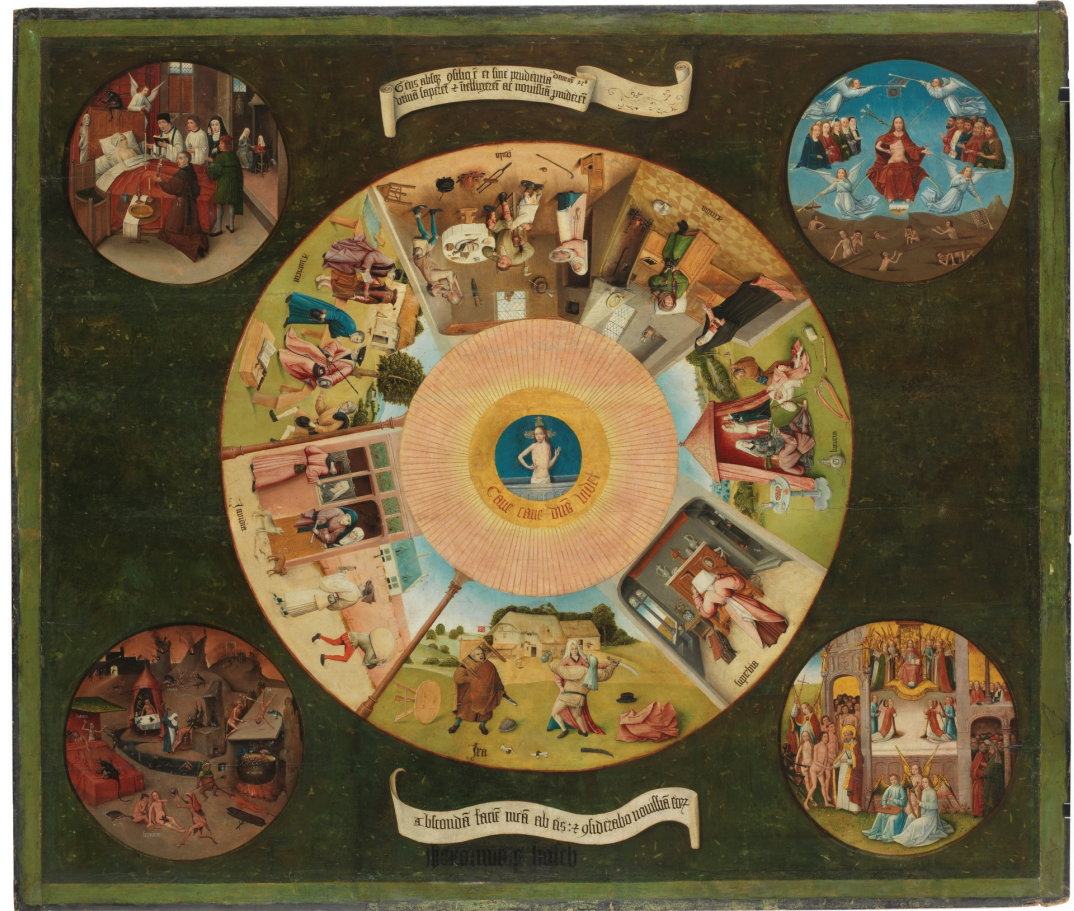

[Figura 01] Hieronymus Bosch, Mesa dos sete pecados mortais e os quatro novíssimos do homem. $1505-1510$.

Óleo sobre mesa de madeira de choupo, $119,5 \times 139,5 \mathrm{~cm}$. Presente no Acervo do Museu do Prado - Espanha. Disponível em <https://www.museodelprado.es/coleccion/obra-de-arte/ mesa-de-los-pecados-capitales/3fcoa84e-d77d-4217-b960-8a34b8873b70> Acesso em: 14 de dezembro de 2019.
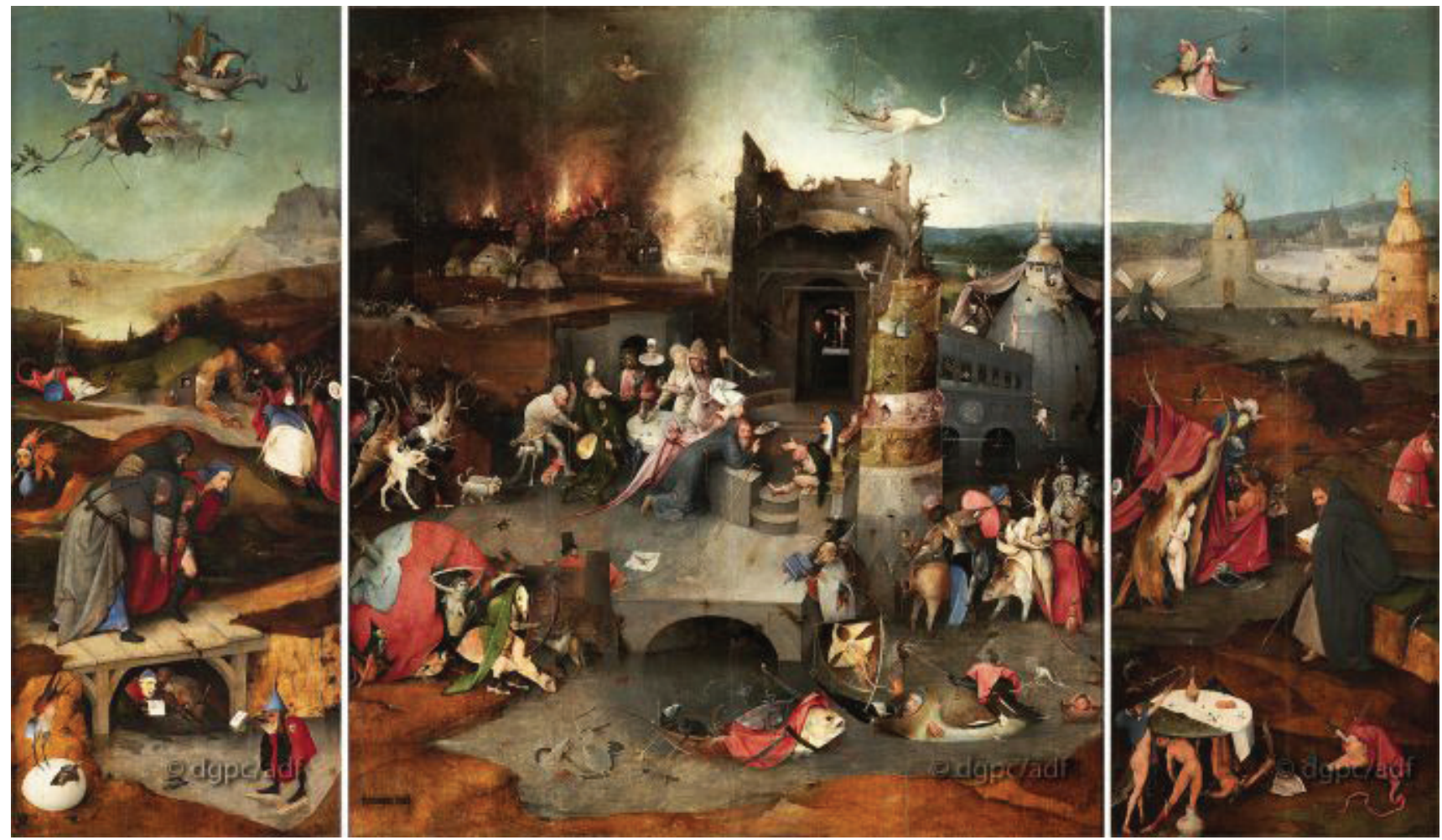

[Figura 02] Hieronymus Bosch, A Tentação de Santo Antônio (15--)

Óleo sobre madeira de carvalho $131,5 \times 119 \mathrm{~cm}$ (painel central) e 131,5 ×53 cm (painéis laterais). Presente no Museu Nacional de Arte Antiga - Portugal. Disponível em <http://www.museudearteantiga.pt/colecoes/pintura-europeia/tentacoes-de-santo-antao> Acesso em: 14 de dezembro de 2019. 
foi o que imaginaram muitos de seus protetores, entre eles príncipes poderosos que vislumbraram, no movimento, a oportunidade de se apropriarem dos bens eclesiásticos, como saída para contornarem a necessidade de dinheiro tanto para sustentar uma administração cada vez mais complexa, quanto para equipar seus exércitos, ou mesmo para adquirir objetos de luxo para a ostentação de sua posição. ${ }^{20}$

Vivenciando tais acontecimentos, o artista e também fiel Jacques Callot (1592-1635) reproduziu em suas obras momentos marcantes da mudança histórica ocorrida no continente europeu. Retratando os acontecimentos da Guerra dos Trinta anos em sua série de gravuras chamada Les misères et les mal-heures de la guerre ${ }^{21}$, realizadas no ano de 1633, demonstrando as faces da guerra religiosa, política e militar, responsável por devastar grande parte da população, gerando uma grande crise no Velho Continente. A ligação do artista francês com a produção de Bosch se deu através da temática religiosa e de caráter maravilhoso, com grande ênfase nas figuras demoníacas e nas representações que apresentavam caráter moral cristão e as relações com os pecados (FICURA 3).

Os sete pecados mortais ${ }^{22}$ representados por Jacques Callot entre os anos de 1618 e 1625 podem ter sido uma primeira visão do mundo que o artista viria a observar durante a Guerra dos Trinta Anos, e ao contrário das cenas cotidianas de Bosch que incluem diversos personagens, o artista utilizou uma escolha iconográfica colocando a figura da mulher como representante da figura do diabo. Fato apontado por Jean Delumeau ${ }^{23}$, como presente no imaginário cristão entre os séculos XIV e XVIII, justificando tratamento da mulher como um ser inferior em relação aos homens. E também afirmado por Robert Muchembled ${ }^{24}$, ao dizer que " No universo em preto e branco dos doutos, a natureza feminina pertencia ao lado sombrio da obra do criador, estando mais próxima do diabo que o homem inspirado por Deus", deixando claro, segundo o autor, a intenção de manter a mulher como ser inferior por natureza e pela vontade divina.

A aparição da figura feminina como representante do diabo está presente na possível última gravura produzida pelo artista no ano de 1635, possuindo também temática análoga à produção de Bosch, quando Callot escolheu demonstrar sua visão sobre as Tentações de Santo Antão (FICURA 4). A caracterização das cenas na representação de Santo Antão por Jacques Callot, une a tradição existente sobre o feminino e a consciência do artista sobre a corrupção do homem diante dos pe-

22 Avareza, Inveja, Ira, Luxúria, Preguiça, Soberba e Gula, produzidas entre os anos de 1618 e 1625, anos iniciais da Guerra dos Trinta Anos.

23 DELUMEAU, Jean, 2009.

24 MUCHEMBLED, Robert, 2001. 

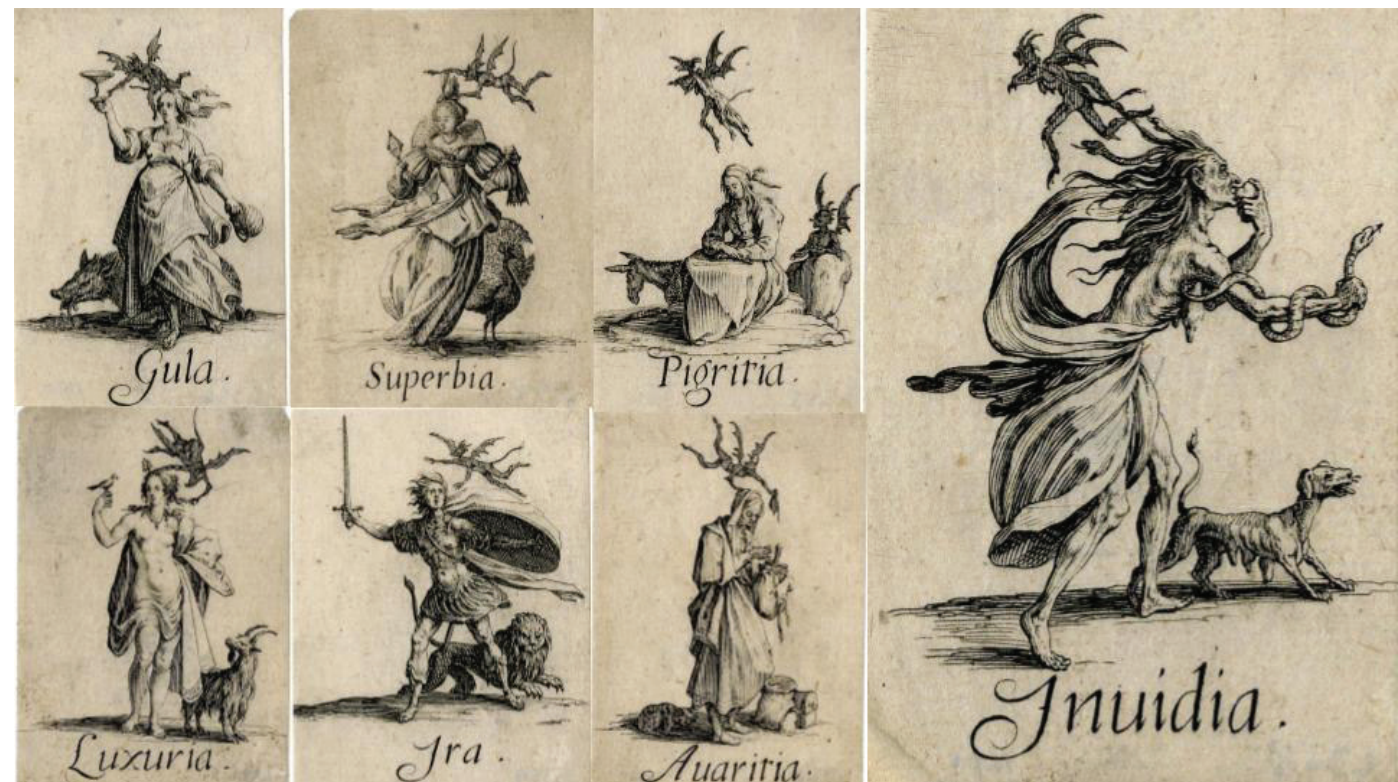

[Figura 03] Jacques Callot, Sete Pecados mortais (1618 - 1625).

Gravura. Altura: 69 milímetros (aparado). Largura: 47 milímetros. Presente no Acervo do Museu Britânico - Reino Unido. Disponível em <https://research.britishmuseum.org/research/collection_online/search.aspx?people=130293\&peoA=130293-2-60> Acesso em: 14 de dezembro de 2019.

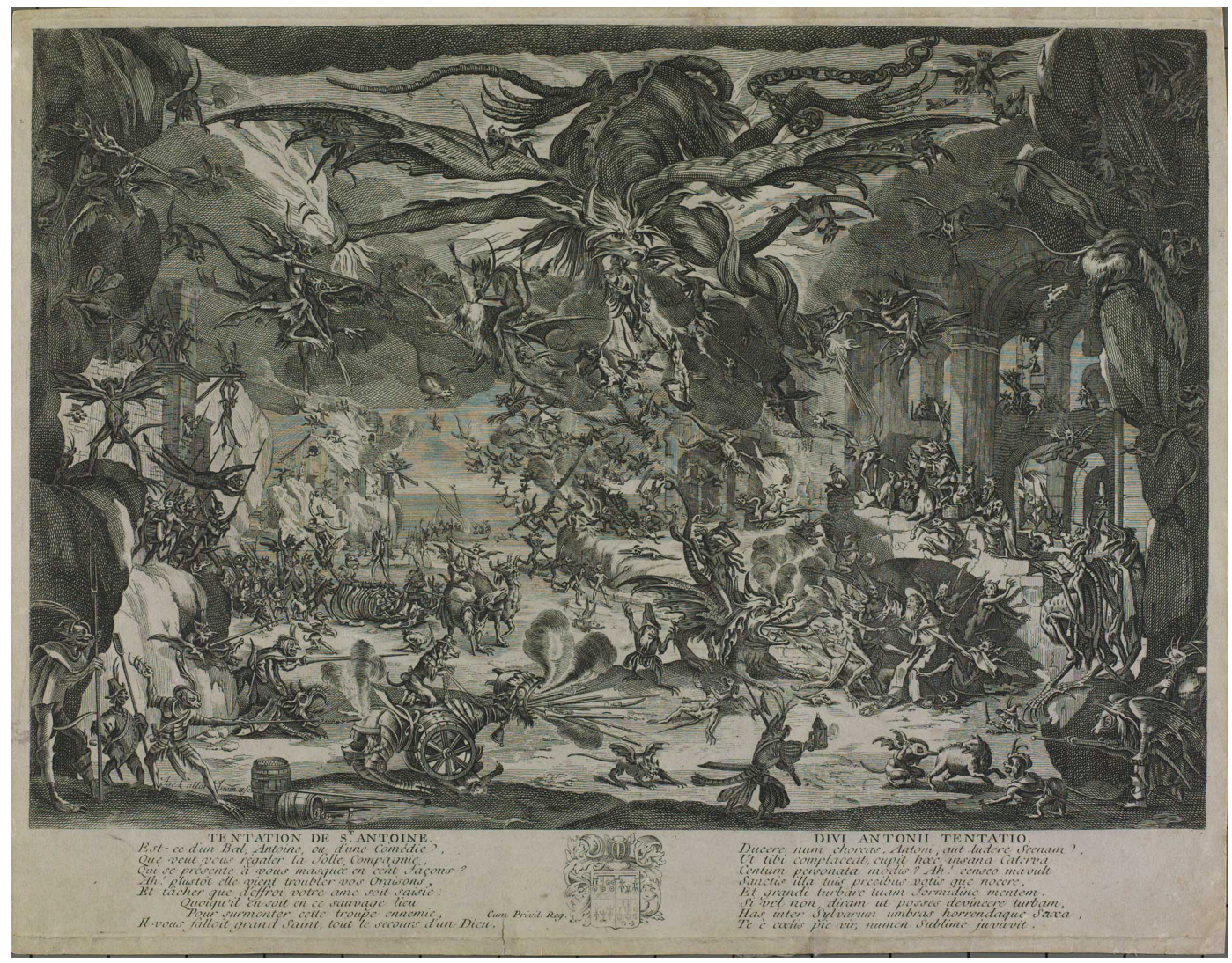

[Figura 04] Jacques Callot, Tentação de Santo Antão (1635).

Água-forte, Preto e Branco; $35,2 \times 47 \mathrm{~cm}$ em papel $36,6 \times 48,7 \mathrm{~cm}$. Presente no Acervo Iconográfico da Biblioteca Nacional do Rio de Janeiro - Brasil. Disponível em <http://objdigital.bn.br/objdigital2/acervo_digital/div_iconografia/ icon1113658/icon1113658.html> Acesso em: 14 de dezembro de 2019. 
cados da guerra, ilustrada através dos diabos que carregam armas e correntes durante o ataque ao santo que resiste pela força de sua fé.

Afirmação importante para a temática de Santo Antão, tendo sua resistência sobre as tentações explicitamente voltadas para o espírito e nunca para o físico, sofrendo todas as investidas do diabo contra seu corpo material sem revidar uma única vez. Demonstração de não resistência física no sentido de não revidar, que está presente principalmente no exemplo do Cristo, mostrado no evangelho de João ao transmitir todo o sofrimento passado de forma pacífica até a crucificação. Exemplo adotado também pelos monges e clérigos responsáveis no início da Igreja Romana como afirma Jean Flori ${ }^{25}$.

O cristianismo, tal como pregado nos primeiros tempos, é uma religião de salvação, pacifista, que preconiza a não violência. Imitando Jesus, que jamais se defendia, os antigos mártires da fé ganhavam o céu perecendo pela espada dos "pagãos" sem opor resistência, sem os combater de espada em punho. [...] Sob a pressão das circunstâncias, por meio de tensões sucessivas, a rejeição à guerra foi-se atenuando. Ela logo foi admitida como um mal menor, um mal necessário. ${ }^{26}$

A utilização das armas pelos cristãos deveria ser justificada de alguma forma, tendo propósitos que levassem a tais atitudes, e esses propósitos foram atingidos com acontecimentos ocorridos contra a Igreja durante o período da Guerra dos Trinta Anos. Desta forma, através destas justificativas, matar não seria necessariamente uma forma de homicídio ou violação das leis divinas, tema abordado por Santo Agostinho, demonstrando que as guerras sempre eram portadoras das desgraças, mas por vezes, um mal necessário na tentativa de evitar desgraças e injustiças ainda maiores contra o povo de Deus.

O mesmo Deus que não seria de todo contrário à violência armada, segundo o argumento desenvolvido em diversas passagens do Antigo Testamento, nas chamadas "guerras do Eterno". Segundo Flori ${ }^{27}$, "a guerra assume valor moral desde que decorra da necessidade de restabelecer pela violência a justiça e a paz rompidas pelo inimigo que assim cometeu uma injustiça, uma falta, um delito", ideal que foi utilizado pelos próprios membros da Igreja para defender suas atitudes no período da Guerra dos Trinta Anos.

Desta forma, a representação de Callot sobre as tentações dentro do contexto histórico de

\footnotetext{
25 FLORI, Jean, 2013.

26 FLORI, Jean, Op. Cit. 2013, p. 16-17.

27 FLORI, Jean, Op. Cit. 2013.
} 
sua produção está recheada de significados além daqueles visíveis, sendo feita através figura do santo, segurando a cruz, como signo da fé cristã e da crença na salvação dos pecados, uma analogia com a figura da Igreja Romana frente aos ataques sofridos no período, em consequência de suas atitudes anteriores. Ataques estes, representados na gravura como executados por diabos que, ao contrário dos de Bosch, com aparência animalesca, assumem um caráter bestial, parte do imaginário presente no período que, segundo Muchembled, se justificava através de diversas contorções intelectuais que buscavam explicar como a partir da sensualidade feminina e de seu envolvimento com o diabo surgiam tais seres monstruosos.

No fundo, é da mulher, de sua sexualidade, do perigo que ela traz em seu seio quando cumpre sua função natural, que se trata. Como as mais diversas precauções não limitam seus apetites excessivos, ela produz monstros se o homem se deixa levar pela via do prazer em vez de pela do dever de procriação ordenado por Deus. ${ }^{28}$

Este caráter bestial é tratado por Tomás de Aquino, definindo a bestialidade como o pior dos pecados sexuais, por não preservar as devidas diferenças entre os seres. Os animais possuem consciência sobre si mesmos, mas não no sentido de gênero essencial ou natural de sua realidade, faltando-Ihes a consciência cujo nome derivaria do termo "saber"29. Consciência esta que permitiria ao ser humano vivenciar, experimentar e compreender os aspectos ou a totalidade de seu mundo interior, demonstrando a superioridade defendida também por Santo Agostinho em sua patrística, ao dizer que, por excelência, o espírito racional dominante sobre todos os demais seres seria melhor e superior aos demais.

Assim, ao formar a composição e inserir características bélicas como lanças, armas de fogo, correntes e formações de grupos diabólicos que marcham em direção ao santo, Callot demonstra sua visão frente aos ataques contra a Igreja. Caráter este reforçado pela figura do dragão presente na composição, um elemento que, segundo Lorenzo Lorenzi ${ }^{30}$, foi representado com as grandes asas membranosas, aparentando-se também com asas de morcego, símbolo de obscuridade, adaptações retiradas da arte chinesa do período Zhou. Algo que, dentro do imaginário coletivo, de acordo com Muchembled ${ }^{31}$, era comumente associada à figura do diabo que assumia não só a forma de dragão contido também nas Sagradas Escrituras, mas de diversos outros seres fantásticos.

\footnotetext{
28 MUCHEMBLED, Robert, 2001, p.109.

29 A conscientia latina provém de scire, saber.

30 LORENZI, Lorenzo, 1997.

31 MUCHEMBLED, Robert, Op. Cit. 2001.
} 
O dragão, presente também na história de outros santos como alegoria da luta da Igreja representante do bem contra o mal. Este mal percebido pelo artista através das atrocidades do período e que pode ter guiado Callot a escolher um dos sete pecados produzidos entre os anos de 1618 e 1635, inserindo-o também em sua última produção. A figura de cabelos terminando em cobras e serpentes que também se enrolam em seu braço representa a injustiça, ligada possivelmente ao pensamento do artista sobre todas as atitudes contra os cristãos do período. Explicitando mais uma vez a forte presença do caráter moral cristão atuante mesmo em um momento tão adverso.

Através da análise dos interesses dos países europeus diante das críticas à lgreja, foi possível encontrar as motivações que levaram as diversas sociedades da Europa a iniciarem a Guerra dos Trinta anos, percebendo que através da posição religiosa dentro da distribuição do capital de autoridade social segundo Bourdieu ${ }^{32}$, seria possível modificar de forma duradoura, tanto as bases ideológicas, quanto as percepções e ações, interferindo diretamente nos campos da religião, economia e da política. Havendo, de um lado, grupos que buscavam manter e aumentar suas riquezas e privilégios aproveitando-se do período de crise da Igreja Católica, e de outro, um conjunto vivendo em condições extremas de pobreza, fome, conflitos e pestes.

Pensamento que pode estar ligado as escolhas iconográficas de Bosch e Callot para representar tanto os sete pecados mortais quanto a vida de Santo Antão, relacionando-os diretamente aos acontecimentos sociais de seus respectivos períodos históricos. Em imagens, repletas de significados que vão além de seus elementos visíveis, reforçando a teoria sobre as funções das imagens, defendidas e fundamentadas por diversos teóricos ao longo da história da Igreja católica, mantendo vivos os ensinamentos desta, mesmo em um momento de crise, fazendo com que os fiéis fossem capazes de relembrar, comover-se através das representações dos pecados e da história de vida de um santo cristão que também enfrentou as tentações do mal e do mundo em busca da salvação.

32 BOURDIEU, Pierre, Op. Cit. 2015. 


\section{Referências bibliográficas}

AGOSTINHO, Santo, Bispo de Hipona. A natureza do bem. 0 perdão dos pecados. 0 batismo das crianças. São Paulo: Paulus, 2019. Coleção Patrística.

AQUINO, Tomás. Suma Teológica. 1265 a 1273.

ATANÁSIO, Santo, Santo Atanásio: Vida de Santo Antão, São Caetano do Sul, SP: Santa Cruz - Editora e Livraria, 2019. BASCHET, Jérôme, L'image. Fonctions et usages des images dans l'Occident médiéval.

BOURDIEU, Pierre. A economia das trocas simbólicas. São Paulo: Perspectiva, 2015.

BOURDIEU, Pierre. O Poder Simbólico. São Paulo: Edições 70, 2011.

BRANDÃO, Jackson. A Guerra Dos Trinta Anos: Imagens De Um Período De Transição, 2012.

Catecismo da Igreja Católica - Edição Típica Vaticana, Edições Loyola; Edição: 19 - 26 de maio de 1999)

DELUMEAU, Jean. História do Medo no Ocidente 1300 - 1800: uma cidade sitiada. São Paulo: Companhia das Letras, 2009.

FISCHER, Stefan, El Bosco: La Obra Completa. Taschen - Bibliotheca Universalis, 2019.

FLORI, Jean. Guerra Santa: Formação da ideia de cruzada no Ocidente cristão. Campinas, São Paulo: Editora Unicamp, 2013.

LITTLE, Lester K. Monges. In: LE GOFF, Jacques, SCHMITT, Jean-Claude. Dicionário Analítico do Ocidente Medieval: Volume 2. São Paulo: Editora Unesp, 2017. p. 256- 275.

LORENZI, Lorenzo. Devils in Art: Florence, from the middle ages to the renaissance. Florence: Centro Di, 1997.

MUCHEMBLED, Robert. Uma História do Diabo: Séculos XII-XX. Rio de Janeiro: Bom Texto, 2001.

QUÍRICO, Tamara. Reforma, Contrarreforma e a expressão religiosa na arte. Rio de Janeiro, Coletânea Rio de Janeiro. Ano XI. Fascículo 21, p.117-140. Jan./Jun, 2012.

SCHMITT, Jean-Claude. Imagens. In: LE GOFF, Jacques, SCHMITT, Jean-Claude. Dicionário Analítico do Ocidente Medieval: Volume 1. São Paulo: Editora Unesp, 2017. p.658 - 674. 